\title{
Annual Cycle of Tropical and Subtropical Total Columnar Ozone and Its Decadal Variability
}

\author{
Vidya S. Pawar ${ }^{1}$, P. S. Salvekar ${ }^{2}$, P. Pradeepkumar ${ }^{3}$ \\ Department of Atmospheric and Space Sciences, Savitribai Phule Pune University, India
}

\begin{abstract}
Total columnar ozone (TCO) variability is studied over tropics $\left(0^{\circ} \mathrm{N}-25^{\circ} \mathrm{N}, 65^{\circ} \mathrm{E}-95^{\circ} \mathrm{E}\right)$ and subtropics $\left(25^{\circ} \mathrm{N}-45^{\circ} \mathrm{N}, 65^{\circ} \mathrm{E}-\right.$ $95^{\circ}$ ) for the period 1979-2012 (except data gap 1993-96) using satellite data. Annual cycle of TCO is examined. The maximum values of TCO over tropics are found in the summer whereas the maxima values over subtropics are in the winter season. Seasonal variation in subtropical TCO shows higher gradient (140 DU) than that of the tropical TCO (gradient is $60 \mathrm{DU}$ ). The conclusions arrived over tropical and subtropical region are found to be valid over micro scale domain as seen from the analysis over smaller region surrounding Thiruvananthapuram $\left(7.5^{\circ} \mathrm{N}-9.5^{\circ} \mathrm{N}, 75.6^{\circ} \mathrm{E}-78.1^{\circ} \mathrm{E}\right)$, Pune $\left(17.5^{\circ} \mathrm{N}-19.5^{\circ} \mathrm{N}, 73.1^{\circ} \mathrm{E}-74.4^{\circ} \mathrm{E}\right)$ and $\mathrm{Delhi}\left(28.5^{\circ} \mathrm{N}-29.5^{\circ} \mathrm{N}, 76.9^{\circ} \mathrm{E}-78.1^{\circ} \mathrm{E}\right)$ using same satellite data sets for 30 years. Further, the seasonal behavior of TCO over global tropical $\left(0^{\circ} \mathrm{N}-25^{\circ} \mathrm{N}\right)$ and subtropical $\left(25^{\circ} \mathrm{N}-45^{\circ} \mathrm{N}\right)$ domain are not affected by changing longitudinal belt.
\end{abstract}

Keywords: Total Columnar Ozone, Tropics, Subtropics, TOMS, Annual cycle of TCO, Decadal variability of TCO

\section{Introduction}

Total Columnar Ozone (TCO) is less than one-millionth of the volume of the atmosphere; still it plays an important role in the global weather and climate. The maximum ozone concentration $(90 \%)$ is found in the stratosphere (good ozone) which shields the Earth's surface from harmful ultraviolet radiation. The remaining ozone concentration about $10 \%$ in the troposphere (Bad Ozone) is also very important as a secondary pollutant, as a naturally occurring gas during Lightning and also as a greenhouse gas. Due to its strong ultraviolet absorption and greenhouse effect, ozone plays an important role in the atmospheric radiation balance [1].

Ozone production mainly takes place in the tropical stratosphere as the direct solar radiation photo dissociates oxygen molecule $\left(\mathrm{O}_{2}\right)$ into oxygen atoms $(\mathrm{O})$, which quickly react with other $\mathrm{O}_{2}$ molecules to form $\left(\mathrm{O}_{3}\right)$. Stratospheric ozone is found in abundance in the higher latitudes rather than in the tropics, that is outside of its natural tropical stratospheric source region. This happens because of the Brewer-Dobson circulation.

Earlier studies reported seasonal cycles, trends, and inter annual variability of tropical ozone [2], [3]. Various studies shows that TCO variability is dominated by (i) annual cycle [2], (ii) quasi biennial oscillation [2]-[8], (iii) El Nino Southern Oscillation [2]-[5] and (iv) solar cycle [2]-[8]. Long-term variations of total ozone over Indian stations have not much addressed till to date except [2] which has discussed spatial and temporal variability of TCO over Indian subcontinent. [5], [9] analyzed the TOMS data from 1979 to 2009 and reported that total columnar ozone (TCO) over the Tibetan plateau is deepening over the last decade. However, the long term change in stratospheric ozone concentration in relation to its natural variability is the current challenge in scientific community.

Present study focuses spatial and temporal TCO variability over tropical $\left(0^{\circ}\right.$ to $\left.25^{\circ} \mathrm{N}\right)$ and subtropical $\left(25^{\circ} \mathrm{N}\right.$ to $\left.45^{\circ} \mathrm{N}\right)$ regions for the period 1979-2012 using satellite data. Similar analysis is also carried out over micro scale domain ,i.e. smaller region surrounding Thiruvananthapuram $\left(7.5^{\circ} \mathrm{N}\right.$ 9.5 $\left.{ }^{\circ} \mathrm{N}, 75.6^{\circ} \mathrm{E}-78.1^{\circ} \mathrm{E}\right)$, Pune $\left(17.5^{\circ} \mathrm{N}-19.5^{\circ} \mathrm{N}, 73.1^{\circ} \mathrm{E}-74.4^{\circ} \mathrm{E}\right)$ and Delhi $\left(28.5^{\circ} \mathrm{N}-29.5^{\circ} \mathrm{N}, 76.9^{\circ} \mathrm{E}-78.1^{\circ} \mathrm{E}\right)$ using same satellite data sets as representing tropics and subtropics.

\section{Data and Analysis}

Satellite observations of ozone have been used in the present study. Daily ozone data from Total Ozone Mapping Spectrometer (TOMS)-Nimbus-7 (1979-1992), TOMSEarth Probe (1997-2005), and Ozone Monitoring Instruments (OMI) (2005-2012) have been used over Indian region $\left(65^{\circ} \mathrm{E}\right.$ to $\left.95^{\circ} \mathrm{E}\right)$. The latitudinal belt from Equator to $25^{\circ} \mathrm{N}$ is considered as tropical region and $25^{\circ} \mathrm{N}-45^{\circ} \mathrm{N}$ is designated as subtropics. To understand the variations in TCO in the 30 year, the time series, of area average daily values are plotted for the period 1979 to 2012 (4 years data gaps from 1993-1996) for each decade separately which helps to determine intra seasonal and inter annual variability of Ozone in the respective decade.

The present study also examines the behavior of total ozone over smaller region of surrounding stations Thiruvananthapuram $\left(7.5^{\circ} \mathrm{N}-9.5^{\circ} \mathrm{N}, 75.6^{\circ} \mathrm{E}-78.1^{\circ} \mathrm{E}\right)$, Pune $\left(17.5^{\circ} \mathrm{N}-19.5^{\circ} \mathrm{N}, 73.1^{\circ} \mathrm{E}-74.4^{\circ} \mathrm{E}\right)$ and Delhi $\left(28.5^{\circ} \mathrm{N}-\right.$ $\left.29.5^{\circ} \mathrm{N}, 76.9^{\circ} \mathrm{E}-78.1^{\circ} \mathrm{E}\right)$ representing tropics and subtropics. In order to get long period 30 year data, three different satellites are considered. It is interesting to note that for the year 2005, two satellites (Earth Probe \& OMI) data are available. Hence, it is possible to compare data of both the satellites.

The annual cycle of TCO is also carried out over 12 different zones of the globe for each $30^{\circ}$ longitudinal belt keeping latitudinal belt as $0^{\circ} \mathrm{N}-25^{\circ} \mathrm{N}$ (tropics) and $25^{\circ} \mathrm{N}$ $45^{\circ} \mathrm{N}$ (subtropics) for the one year 2005 . These 12 different zones are considered as: (i) Indian region $\left(65^{\circ} \mathrm{E}\right.$ to $\left.95^{\circ} \mathrm{E}\right)$, (ii) East Asia $\left(95^{\circ} \mathrm{E}\right.$ to $\left.125^{\circ} \mathrm{E}\right)$, (iii) West pacific $\left(125^{\circ} \mathrm{E}\right.$ to $\left.155^{\circ} \mathrm{E}\right)$, (iv) Marshal island-Central Pacific Ocean $\left(155^{\circ} \mathrm{E}\right.$ to $\left.5^{\circ} \mathrm{W}\right)$, (v) Hawai, Pacific Ocean $\left(5^{\circ} \mathrm{W}\right.$ to $\left.35^{\circ} \mathrm{W}\right)$, (vi) East Pacific $\left(35^{\circ} \mathrm{W}\right.$ to $\left.65^{\circ} \mathrm{W}\right)$, (vii) Mexico $\left(65^{\circ} \mathrm{W}\right.$ to $95^{\circ} \mathrm{W}$ ), 


\section{International Journal of Science and Research (IJSR) \\ ISSN (Online): 2319-7064 \\ Index Copernicus Value (2013): 6.14 | Impact Factor (2015): 6.391}

(viii) Carribian sea $\left(95^{\circ} \mathrm{W}\right.$ to $\left.125^{\circ} \mathrm{W}\right)$, (ix) Atlantic Ocean $\left(125^{\circ} \mathrm{W}\right.$ to $\left.155^{\circ} \mathrm{W}\right)$, (x) West Africa $\left(155^{\circ} \mathrm{W}\right.$ to $\left.5^{\circ} \mathrm{E}\right)$, (xi) Central Africa $\left(5^{\circ} \mathrm{E}\right.$ to $\left.35^{\circ} \mathrm{E}\right)$, (xii) Saudi Arabia $\left(35^{\circ} \mathrm{E}\right.$ to $\left.65^{\circ} \mathrm{E}\right)$.

\section{Results and Discussion}

Daily TCO is plotted for tropics and subtropics for each year separately and are presented in Figure 1 for three decades (1979-2012). The results in the figure explain annual and decadal variability of tropical and subtropical TCO. In tropics TCO is higher in summer season (June to September), maxima varying in the range 280-290 DU and is lower in winter season (December to March), minima varying in the range 235-245 DU (Left panel of Fig 1). On the other hand, in subtropics TCO is higher in late winter/early spring season (Feb to March) and maxima is varying in the range $370-380$ DU and is lower in summer season (June to September), minima varying in the range 240-260 DU (Right panel of Fig 1). The difference between maximum and minimum value of TCO is designated as gradient. Seasonal variation in subtropical TCO shows higher gradient $(140 \mathrm{DU})$ than that of the tropical TCO (gradient is $60 \mathrm{DU}$ ) it may be noted that the magnitudes of subtropical TCO are also higher than the tropical TCO (Fig.1). Further, it is interesting to note that during summer (Jun-Sep) the range of TCO magnitudes in the tropics and subtropics are close to each other in all the three decades. It is also noted that TCO is reducing in the last decade in particular TCO maximum values are decreasing during summer (winter) in tropics (subtropics)

The analysis of TCO is also carried out over micro scale domain of tropical stations Thiruvananthapuram $\left(7.5^{\circ} \mathrm{N}\right.$ 9.5 $\left.{ }^{\circ} \mathrm{N}, 75.6^{\circ} \mathrm{E}-78.1^{\circ} \mathrm{E}\right)$, Pune $\left(17.5^{\circ} \mathrm{N}-19.5^{\circ} \mathrm{N}, 73.1^{\circ} \mathrm{E}-74.4^{\circ} \mathrm{E}\right)$ and subtropical station Delhi $\left(28.5^{\circ} \mathrm{N}-29.5^{\circ} \mathrm{N}, 76.9^{\circ} \mathrm{E}-\right.$ $78.1^{\circ} \mathrm{E}$ ) and are presented in Figure 2. The tropical stations (Thiruvananthapuram, Pune) follow the pattern same as that seen for tropics (Figure 1, Left Panel), i.e. TCO is higher (lower) in summer (winter) season. Seasonal behavior of tropical stations shows, ozone maxima varying in the range 280-290 DU and minima varying in the
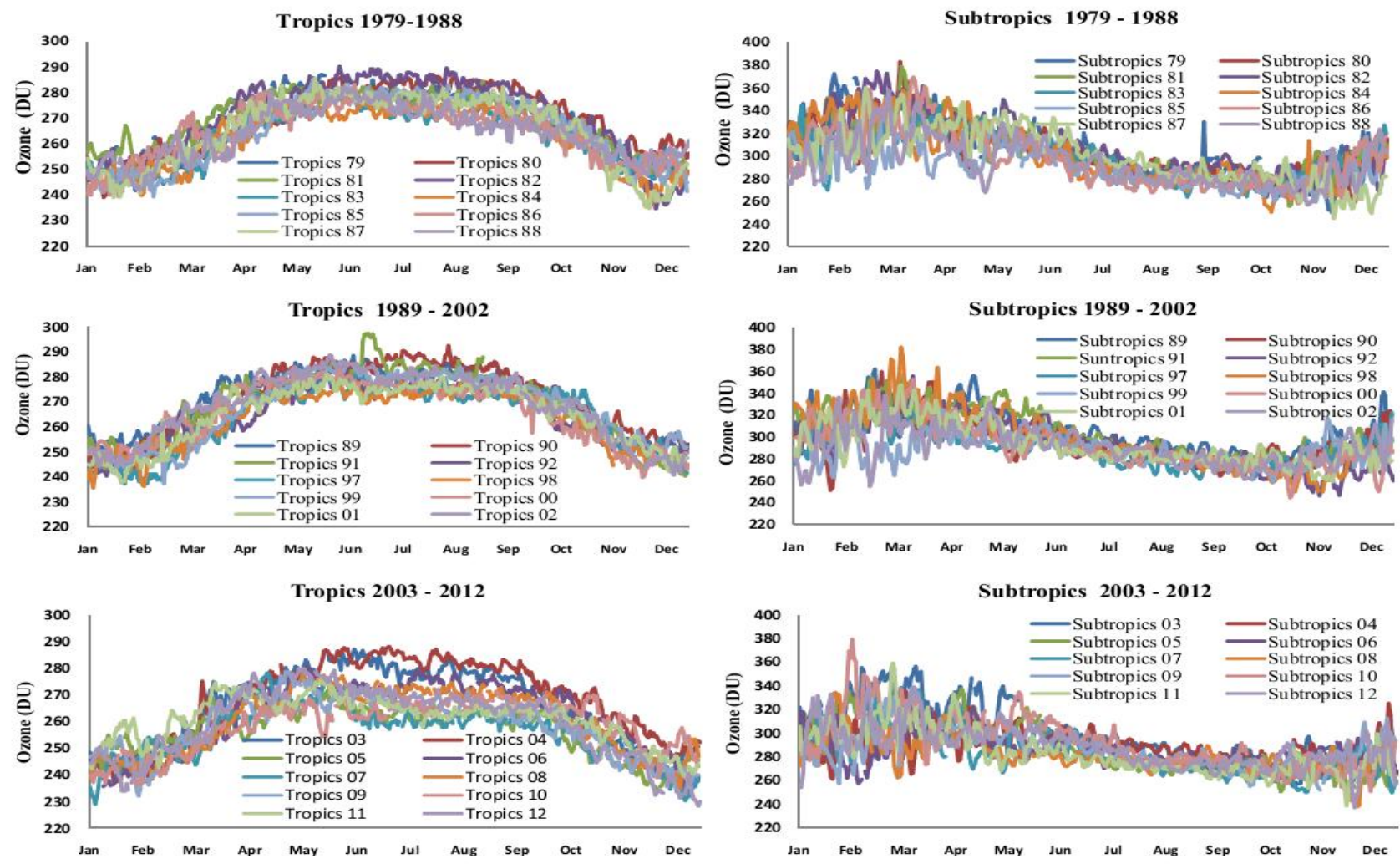

Figure1: Variability of total columnar ozone for the years 1979 to 2012 over belt $65^{\circ} \mathrm{E}-95^{\circ} \mathrm{E}$ for tropics (Left Panel) and for subtropics (Right Panel). 


\section{International Journal of Science and Research (IJSR) \\ ISSN (Online): 2319-7064}

Index Copernicus Value (2013): 6.14 | Impact Factor (2015): 6.391

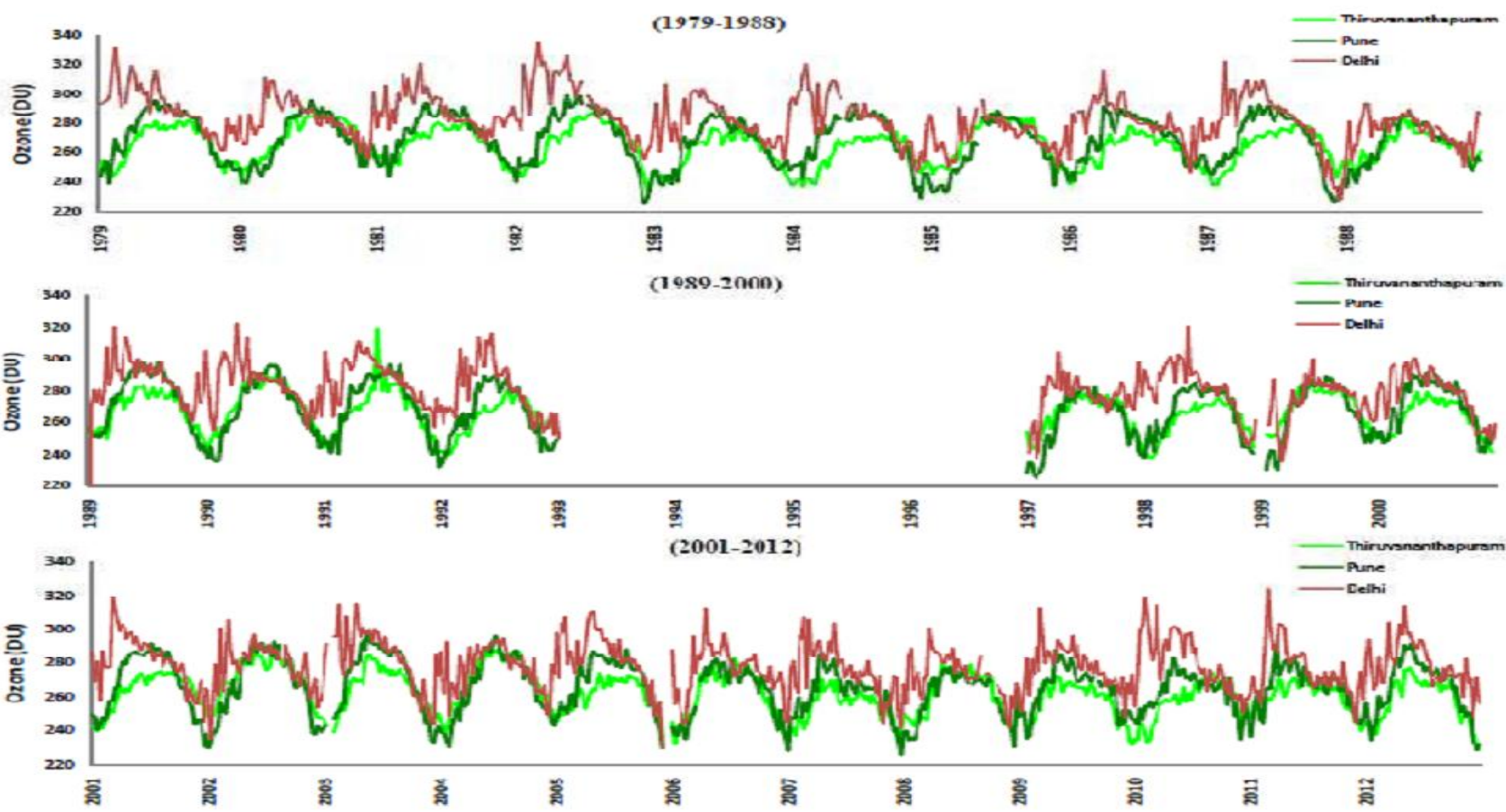

Figure 2: Behavior of total columnar ozone over micro scale region $\left(2^{\circ} \mathrm{x} 2^{\circ}\right)$ for the years 1979 to 2012

(Tropical Stations: Thiruvananthapuram, Pune; Subtropical Station: Delhi)

range 222-242 DU. In particular the gradient for Thiruvananthapuram and Pune is 38 DU to 58 DU respectively. This shows that the behavior between TCO over a small region (tropical stations) is similar to the behavior obtained over larger region (Fig 1). On the other hand from Figure 2 we can see that the subtropical station Delhi follows the subtropical behavior (Figure 1, Right Panel) of TCO i.e. ozone is higher (lower) in late winter/early spring (winter) season Feb to March (December to March). Over Delhi region TCO maxima vary in the range 320-330 DU and its minima varying in the range 230240 DU. Seasonal variation of TCO over subtropical station (Delhi) has higher gradient (90 DU) than that of the tropical station Thiruvananthapuram, Pune (ozone gradient is $38 \mathrm{DU}$ and $58 \mathrm{DU}$ ) and in general the magnitude of TCO becomes higher over the region away from equator towards northern latitude (Fig. 1 and Fig. 2).

As already mentioned for the year 2005 TCO data is available from Earth Probe and OMI. Therefore, the data from both satellites are compared for tropics and subtropics over $65^{\circ} \mathrm{E}-95^{\circ} \mathrm{E}$ belt. The time series for one year of TCO is plotted in Fig 3.

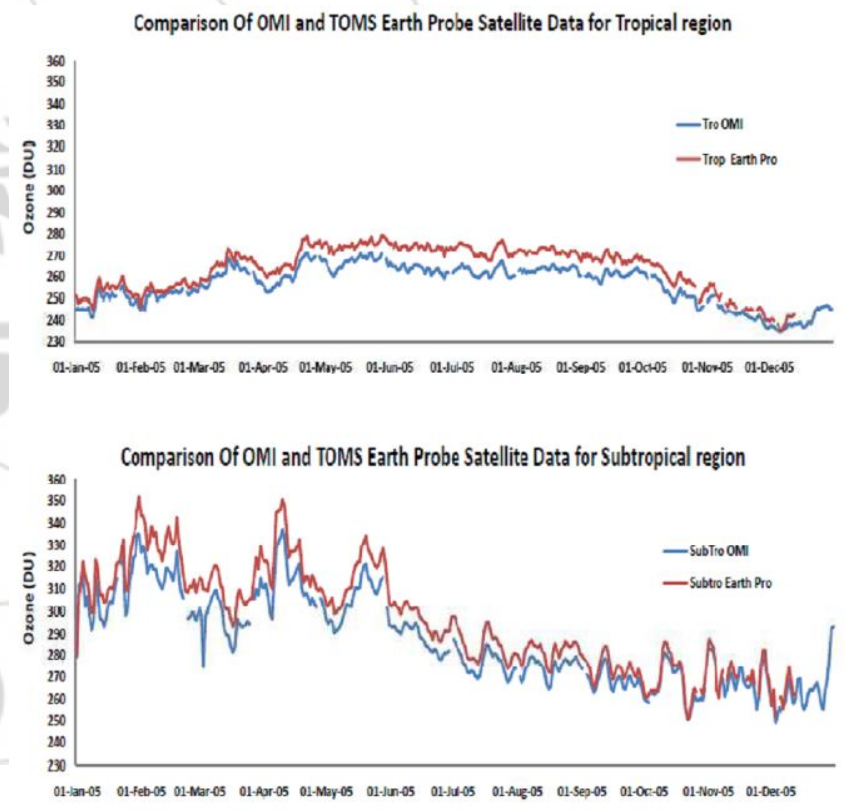

Figure3: Comparison of TOMS OMI and TOMS Earth Probe Satellite Ozone data for the year 2005 over tropical and subtropical region of $65^{\circ} \mathrm{E}-95^{\circ} \mathrm{E}$

It is seen that in general, data from both satellites are close to each other. The TCO values differ by about 3 to 5 DU during summer (winter) in tropics (subtropics).

TCO variability is also studied over 12 different zones covering entire globe. Since OMI satellite data is available from year 2005, the seasonal variability of TCO, for 12 different zones (the 12 zones are described in the section 2) is examined for the year 2005 and is shown in the Fig. 4. It is interesting to note that seasonal variability of TCO for all the zones is similar to that, obtained for Indian region (Fig. 1). From the figure it is clearly seen that tropical region of all the 12 zones show TCO is higher in summer season (June 


\section{International Journal of Science and Research (IJSR) \\ ISSN (Online): 2319-7064 \\ Index Copernicus Value (2013): 6.14 | Impact Factor (2015): 6.391}

to September), maxima varying in the range 270-280 DU and is lower in winter season (December to March), minima varying in the range 235-245 DU. On the other hand, in subtropical region of all the 12 zones show TCO is higher in late winter/early spring season (Feb to March) with maxima varying in the range (370-380 DU) and TCO is lower in summer season (June to September) with minima varying in the range $240-260 \mathrm{DU}$.

\section{Conclusions}
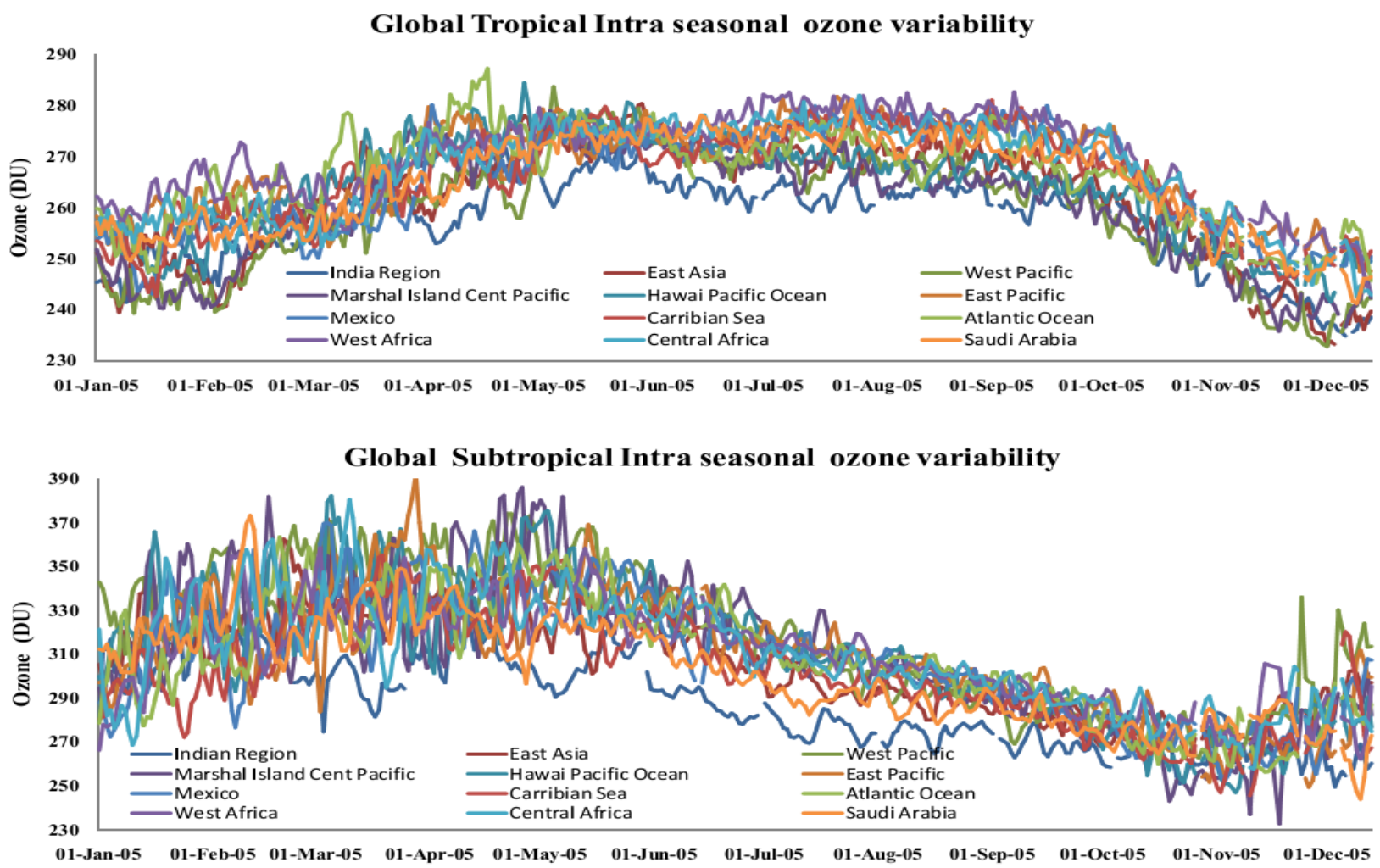

Figure 4: Global intra seasonal total columnar ozone variability over tropics (Upper Panel) and subtropics (Lower Panel) for the year 2005

\section{Acknowledgements}

Analyses and visualizations for ozone used in this paper were produced with the Giovanni online data system, developed and maintained by the NASA GES DISC (http:// giovanni.sci.gsfc.nasa.gov). First author is thankful to UGCRGNF for the fellowship support during the research work period. We are also thankful to Dr.Rohini Bhawar, Dr.G.B. Pant, Dr.P.N. Sen and Dr. K.C. Sinha Ray for their useful discussion.

\section{References}

[1] Foster, P. and Shine, K (1997) Radiative forcing and temperature trends from stratospheric ozone changes, Journal of Geophysical Research, 102, 10841-10855.

[2] Madhu, V. (2014) Spatial and Temporal Variability of Total Column Ozone over the Indian Subcontinent: A Study Based on Nimbus-7 TOMS Satellite.
The analysis of ozone for three decades (1979-2012) over Indian longitudes inferred that in tropics $\left(0^{\circ}-25^{\circ} \mathrm{N}, 65^{\circ} \mathrm{E}-\right.$ $95^{\circ} \mathrm{E}$ ) TCO shows increasing (decreasing) phase in summer (winter). In subtropics $\left(25^{\circ} \mathrm{N}-45^{\circ} \mathrm{N}, 65^{\circ} \mathrm{E}-95^{\circ} \mathrm{E}\right)$ during late winter/early spring season TCO is showing increasing phase. Seasonal variation in subtropical TCO shows higher gradient $(140 \mathrm{DU})$ than that of the tropical ozone (gradient is $60 \mathrm{DU})$. The conclusions arrived over tropical and subtropical region are found to be valid over micro scale as well as large scale domain are in good agreement using satellite observations. TCO values are obtained from OMI and Earth Probe is comparable for the year 2005. It is also found that seasonal variations of TCO are independent of longitudinal belt. 


\section{International Journal of Science and Research (IJSR) \\ ISSN (Online): 2319-7064}

Index Copernicus Value (2013): 6.14 | Impact Factor (2015): 6.391

in equatorial total ozone. J. Geophys.Res., 97, 76257633.

[8] Chandra, S. and McPeters, R. D., (1994) The solar cycle variation of ozone in the stratosphere inferred from Nimbus-7 and NOAA 11 satellites. J. Geophys. Res., 99, 20665-20671.

[9] Ye, Z. J. and Xu, Y. F. (2003), Climate characteristics of ozone over Tibetan Plateau. J. Geophys. Res. 108(D20), 4654.

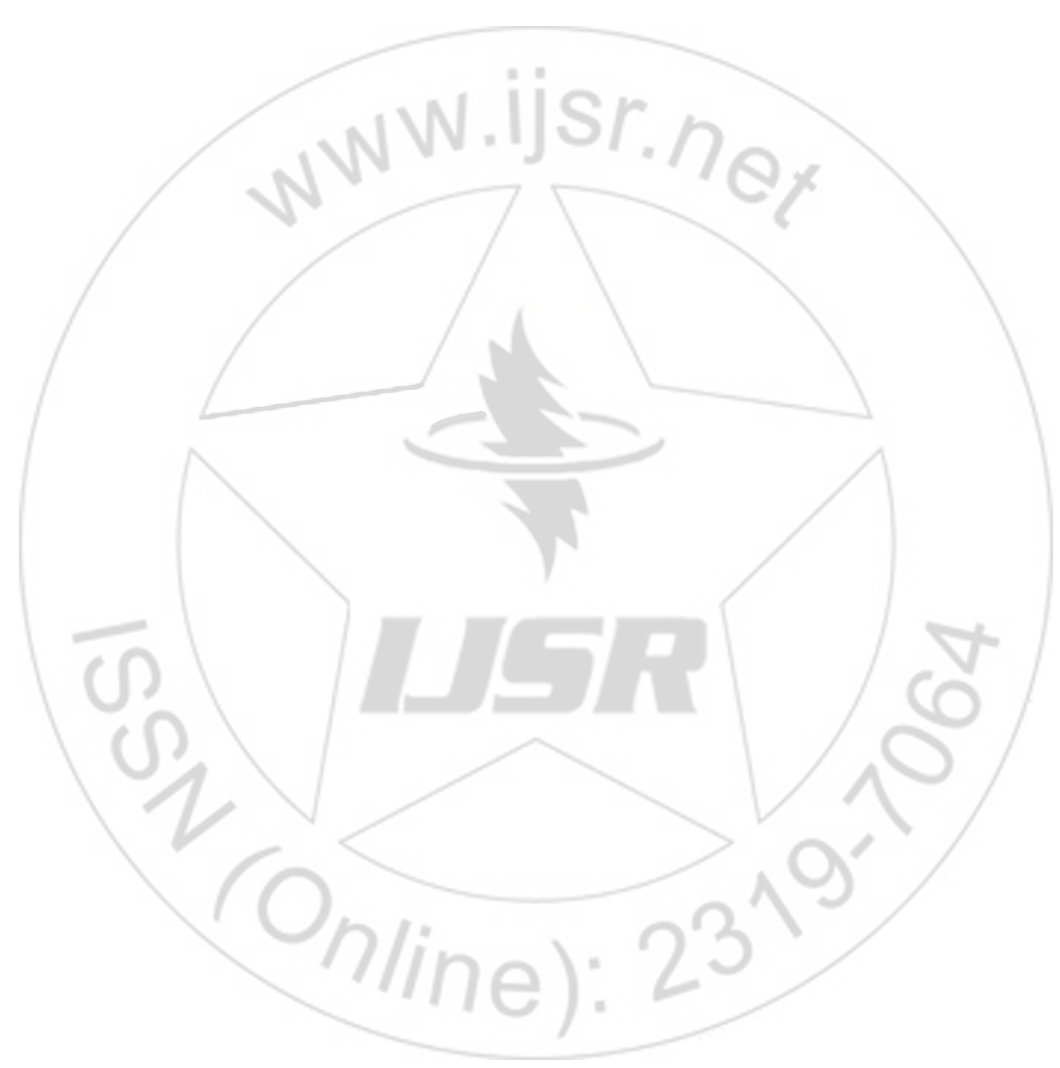

Volume 5 Issue 5, May 2016 